Article

\title{
Relational Communication Spaces: Infrastructures and Discursive Practices
}

\author{
Alexa Keinert ${ }^{1, *}$, Volkan Sayman ${ }^{2}$ and Daniel Maier ${ }^{3}$ \\ ${ }^{1}$ Department of Political and Social Sciences, Freie Universität Berlin, Germany; E-Mail: a.keinert@fu-berlin.de \\ 2 Institute of Sociology, Technical University of Berlin, Germany; E-Mail: sayman@tu-berlin.de \\ ${ }^{3}$ German Cancer Consortium, Heidelberg, Germany; E-Mail: daniel.maier@kgu.de \\ * Corresponding author
}

Submitted: 31 December 2020 | Accepted: 7 May 2021 | Published: 23 July 2021

\begin{abstract}
Digital communication technologies, social web platforms, and mobile communication have fundamentally altered the way we communicate publicly. They have also changed our perception of space, thus making a re-calibration of a spatial perspective on public communication necessary. We argue that such a new perspective must consider the relational logic of public communication, which stands in stark contrast to the plain territorial notion of space common in communication research. Conceptualising the spatiality of public communication, we draw on Löw's (2016) sociology of space. Her relational concept of space encourages us to pay more attention to (a) the infrastructural basis of communication, (b) the operations of synthesising the relational communication space through discursive practices, and (c) power relations that determine the accessibility of public communication. Thus, focusing on infrastructures and discursive practices means highlighting crucial socio-material preconditions of public communication and considering the effects of the power relations which are inherent in their spatialisation upon the inclusivity of public communication. This new approach serves a dual purpose: Firstly, it works as an analytical perspective to systematically account for the spatiality of public communication. Secondly, the differentiation between infrastructural spaces and spaces of discursive practices adds explanatory value to the perspective of relational communication spaces.
\end{abstract}

\section{Keywords}

discursive practices; inclusion; infrastructures; methodological nationalism; networks; public communication; sociology of space; territory

\section{Issue}

This article is part of the issue "Spaces, Places, and Geographies of Public Spheres" edited by Annie Waldherr (University of Vienna, Austria), Ulrike Klinger (European University Viadrina, Germany) and Barbara Pfetsch (Freie Universität Berlin, Germany / Weizenbaum-Institute for the Networked Society, Germany).

(C) 2021 by the authors; licensee Cogitatio (Lisbon, Portugal). This article is licensed under a Creative Commons Attribution 4.0 International License (CC BY).

\section{Introduction}

Analyses of public communication and concepts of the public sphere have always been linked to questions of citizenship and polity (e.g., Fraser, 2014). The notion of a public sphere as an intermediary sphere for discourse between representatives of the political system and society is conceptually bound to the nation-state. However, we question whether the nation-state should still be considered the default geospatial reference of public communication-given that hybrid communication ecologies have developed in the past two decades (Chadwick, 2011). While the dominance of methodological nationalism in the social sciences has long been criticised (e.g., Volkmer, 2014, pp. 11-13), the emergence of digital networks has made the re-calibration of a spatial perspective on public communication even more pressing. 
We argue that such a new perspective must consider the relational logic of networked public communication and digital technology, which stands in stark contrast to a plain territorial notion of space (e.g., Kavada \& Poell, 2020). In the digital age, public discourse has loosened its ties from territorial arenas (e.g., Heft et al., 2021). Recent descriptions understand public communication as networks in which individuals and collectives connect to exchange information and opinions (e.g., Friedland et al., 2006). Empirical studies provide evidence that these networks exhibit specific spatial patterns. For example, people living close to one another connect much more frequently than the geographically distant, and cosmopolitan cities have greater salience in those networks than other cities and regions (e.g., Takhteyev et al., 2012). Thus, we see that public communication is spatially structured, but a territorial understanding of space alone is insufficient to properly comprehend its structure. Therefore, we propose the concept of 'relational communication spaces' which offers the tools to systematically consider and investigate the spatiality of public communication while refraining from presupposing a default spatial form or logic of public communication. In our understanding, public communication is communication that: (1) addresses a public, which means a collective that potentially includes strangers (Klinger, 2018, p. 259); and/or (2) is accessible to others (such as social media posts or conversations in public space).

For our theoretical endeavour, we draw on the sociology of space. We show that this theoretical framework serves well as a basis to identify specific spatial figures in the empirical analysis of communication phenomena. More specifically, we build on the concept of relational spaces, which emerge as "relational arrangement[s] of living beings" and things (Löw, 2016, p. 131). These arrangements structure human actions and are simultaneously structured by human agency. Thinking about public communication with the terms and conceptual tools provided by Löw's sociology of space, we can conceive of specific spatialisations of public communication as a relational communication space shaped by the complex intermeshing of infrastructured spaces and the spatial patterns of discursive practices. The two central socio-material building blocks of relational communication spaces are infrastructures and discursive practices. Other spatial dimensions of public communication, specifically the discussion of places (and their meaning), are not the focus of our concept. Since all communication is inherently relational, the term 'relational communication space' may seem tautologic at first glance. However, the emphasis on the relational character serves to contrast an absolutist (i.e., space simply exists and is a container of social processes) or relativist (i.e., space emerges out of relations between things while humans are not included) understanding of space (Löw, 2016).

We argue that infrastructures and discursive practices are central building blocks of relational communi- cation spaces; their spatialisation shapes who can participate in public communication and how. Fundamentally, the question of the spatiality of public communication is a question of participation and inclusion. Technical and social infrastructures are the foundations from which public discourse emerges (Marres \& Lezaun, 2011, p. 496; Pfetsch et al., 2019, p. 97)-and these are usually spatially bound. Whether one has access to, for example, a stable and fast internet connection or an education in media literacy, depends on where one lives and how resources are allocated there. Despite their often "hard-wired" nature, infrastructures are subject to human agency and the exercise of economic and political power (Müller et al., 2017, pp. 5-6). Discursive practices in turn are structures of meaning and knowledge production as well as circulation (Keller, 2005). Parallel to infrastructures, discursive practices exhibit a spatial pattern depending on the issue around which public communication evolves and presuppose basic competencies such as the mastery of a local language.

In the remainder of this article, we argue that the concept of relational communication spaces makes relevant aspects of public communications' complex spatial structuring visible and accessible for empirical research. We explain why this concept is sensitive to the power relations ingrained in the spatial distribution of discursive practices and communication infrastructures. Then, we demonstrate how the concept of relational communication spaces translates into strategies for empirical research. Finally, we conclude that the concept of relational space provides an analytical grid to reveal the spatiality of public communication which illuminates questions of participation, visibility, and exclusion.

\section{The Spatiality of Public Communication}

\subsection{Conceptualising the Spatiality of Public Communication: A Desideratum}

The study of public communication in the digital age requires a rigorous revision of the assumptions about the spatiality of public communication. Such a revision should unveil spatialisations of communication beyond the territories of cities, nation-states, or other 'container spaces.' This is not to say that territory has become irrelevant, but that it is only one spatial figure among othersin contrast to what has been criticised as methodological nationalism. According to Wimmer and Schiller, methodological nationalism is a "coherent epistemic structure" (2002, p. 308), that takes the nation-state or society as the default unit for empirical analyses. This has also been the case in theory development and research on the public sphere and public communication. Among others, Fraser has criticised the "Westphalian blindspot" (2014, p. 19) in Habermas' Structural Transformation of the Public Sphere, this blind spot being a conceptualisation of the public sphere tied to a bounded political community and territory. This liaison made sense as the 
concept of the public sphere developed following the rise of democratic nation-states in Western Europe in the 20th century. However, the concept of a national public sphere has always missed forms of public communication that take place on other scales (such as the translocal level; e.g., Wehden \& Stoltenberg, 2019) and alternative spaces of discourse with their own infrastructures of communication (as described in the concept of "subaltern counterpublics" by Fraser, 1990, p. 67). With digital media and social networking platforms, those alternative spaces have become more visible as well as accessible to more people and now compete with massmediated, national arenas of public discourse (Friedland et al., 2006, p. 8).

In communication studies, many concepts such as the public sphere refer to a spatial dimension. However, a systematic scrutinisation of spatiality as an explanatory factor in empirical analyses is missing in most cases (Wehden \& Stoltenberg, 2019, p. 1401). In regards to research on public communication, particular spaces and places have been described as a constitutive element of the public sphere (e.g., Habermas, 1962/2013, pp. 92-98.). Other vital research fields referring to the spatiality of public communication are comparative studies of communication systems in different countries (Hallin \& Mancini, 2004), digital divide research focusing on spatially bound disparities regarding access to and use of digital services (e.g., Stern et al., 2009), the conceptualisation of proximity as a news value (e.g., Schulz, 1990), research on news geography (e.g., Wilke et al., 2012), descriptive studies of local and municipal media landscapes in the 1980s (see Beck, 2003, for a summary), or works on transnational public spheres (e.g., Heft et al., 2021).

While recent contributions on the transnationalisation of public spheres (e.g., Couldry, 2014, pp. 52-53), the rise of global social movements (e.g., Tarrow \& McAdam, 2005), media history (Schüttpelz, 2017), issue publics (e.g., Marres, 2007, p. 371), and global communication networks (e.g., Friedland et al., 2006; Volkmer, 2014) have increasingly questioned the dominance of national public spheres, their notion remains powerful (Korn et al., 2019, p. 21). Inspired by these writings, we propose a spatial perspective on public communication that moves beyond the Westphalian blindspot.

\subsection{Relational Concept of Space}

Research on material politics (e.g., Marres \& Lezaun, 2011) and the affordances of platforms (e.g., Colleoni et al., 2014, p. 329) emphasise that public communication emerges from human interactions with, or based on, infrastructure. Ethnographic research investigating media production sites shows that they result from an "entanglement" of various human and non-human actors (Bonini \& Gandini, 2020, p. 3), thus emphasising the relationality inherent to the production process. Moreover, humans, their interactions, and the infras- tructure they use operate on different scales: One can talk about local issues even whilst situated at another place by using globally operating platforms such as Twitter (e.g., Wehden \& Stoltenberg, 2019). Löw's concept offers us the framework to combine structure and interaction in thinking about the spatiality of public communication. Löw defines space as a "relational arrangement of living beings and social goods" (2016, p. 131). The core of this understanding of space lies in two processes: the placement of social goods and living beings at locations ('spacing'), and the 'synthesis' of space comprising those social goods and beings via "sensual, affective and conscious" and discursive processes such as mappings and genres of talk (Knoblauch \& Löw, 2017, p. 5). What does this mean for a relational theory of public communication? The relational concept of space encourages us to pay more attention to (a) social goods and the infrastructural basis of communication and (b) operations of synthesising communication spaces through collective discursive practices. While the processes of spacing and synthesis alone provide little information about how the processes of space creation are regulated, our case of public communication renders visible normative implications of these processes. The concept points to (c) power relations governing access to material and social infrastructures and the knowledge of discursive practices (Adams \& Jansson, 2012, p. 310).

We want to highlight three aspects of Löw's definition of space, which demonstrate why this concept particularly fits our purpose: First, human beings play an essential role in the constitution of space, for example through communication. Consequently, space needs to be understood as inherently social. Even though Löw speaks of "living beings" in her definition, and includes non-human beings in principle (2016, p. 131), we will focus here on humans as communicating actors. Humans constitute spaces in a dual sense: In a constructivist sense, humans process their surroundings cognitively and affectively; thus, they synthesise spatial arrangements. Equally important, humans actively place goods and other humans in their physical environments while also being passive subjects in such processes, which matches the interactive nature of communication. Second, the term 'arrangement' implies that space is the result of a process. Although spaces can become institutionalised, they do not "simply exist" but are "created in action" (Löw, 2016, p. 145). Spaces, understood as arranged goods and beings, are constantly subject to change: such arrangements can dissolve or be rearranged. This characteristic appears particularly important in the context of highly dynamic communication spaces (e.g., Korn et al., 2019, p 21). Finally, the term 'relational' emphasises that space is a product of putting objects and beings into relation (Löw, 2016, S106). Taken together, the constant interaction between synthesis and spacing makes it possible to speak of an infrastructured space from which relational 
communication spaces emerge (Schäfer \& Wessler, 2020, p. 315).

\subsection{Building Blocks of Relational Communication Spaces}

In the context of public communication, social goods are infrastructures that enable the emergence of debate (e.g., Pfetsch et al., 2019, p. 97) or the "experiences of publicness" (Abidin, 2021, p. 4). They can materialise in the form of social networking platforms, print media, fibre optic cables, or public spaces in cities. Other forms of infrastructures include social infrastructures such as educational institutions disseminating knowledge about media literacy or people with explicit knowledge in, and implicit embodied knowledge of, discursive practices. The way infrastructures are economically and politically governed as well as their spatial scope also prestructure which sorts of relational communication space emerge. In other words, it matters which social goods form infrastructures constituting spaces of public communication as they pose "different demands on synthesis" (Knoblauch \& Löw, 2017, p. 5).

For social goods and living beings to constitute space, they not only need to be placed but also synthesised in order to construct an abstract whole from the social goods and humans linked through spacing. Although Löw conceptualises synthesis mainly as an individual process, such as memorising or the mere processing of the environment (2016, p. 135), it can also be related to communication practices on the level of social interaction as these processes feed into shared norms and routines of discursive practices. Importantly, these practices are increasingly digitally mediated and are primarily organised by discursive knowledge orders (Reckwitz, 2008). In the context of public and especially digital communication, speakers must imagine an audience or community which they address, since the recipients are dispersed (e.g., Litt \& Hargittai, 2016). Imagining them as a counterpart, thereby putting oneself in relation to others, opens the space for public communication. Simultaneously, the practices have a spatial notion: be it the imagined audience that is concentrated locally or geographically dispersed or the collective memory of groups of people that share experiences and memories due to where they live (in different regions and nations, in an urban or rural setting).

Addressing the spatiality of infrastructures and discursive practices of public communication means considering processes of power and inequalities. Infrastructures and knowledge about discursive practices and the use of infrastructures are spatially centred, unequally distributed or fragmented (e.g., Meusburger, 2001). Two questions are relevant in this context: Who has access to infrastructures and knowledge about their use? And who is ultimately involved in public communication? The latter is inherently conditioned by the question of access, but access does not necessarily yield participation. It should also be emphasised that this perspective can bring into focus not only processes of exclusion, but also of inclusion through, for example, the lower barriers to publication made possible by digital media. In refraining from presupposing a certain spatialisation of public communication, we do not suggest a "wholeness" of publics, encompassing everyone in a territory or a perfectly connected network. This can make our framework attractive to research looking into disconnections (Pfetsch, 2018), public communication of marginalised groups in counter publics, or "refracted publics" (Abidin, 2021).

So far, we have talked about the spatialisation of public communication in a rather abstract way; however, it is worth considering the concrete spatial forms by which public communication could be structured. Summarising the state of research, Löw distinguishes four spatial figures: territory, network, place, and trajectory (2020, p. 153). These serve as heuristics in the description and empirical analysis of relational communication spaces. Territory describes an idea of space as a surface or container, that is, a space defined by its boundaries and which thus establishes an inside and an outside (logic of differentiation; Knoblauch \& Löw, 2020, p. 273). Many legacy mass media, for example, correspond to a territorial logic and are aligned in their distribution to the borders of nation-states, cities, or language areas (Schüttpelz, 2017, pp. 27-28). With the emergence of digital media, public communication has increasingly been thought of as a network, in which also legacy media are included, as these platforms enable follow-up communication as well as networking across national and linguistic boundaries (e.g., Neuberger, 2017). But it is not only with the spread of digital communication infrastructures that network spaces emerge; we also understand road or electricity grids as networks because they follow the logic of connectivity. Places play a role in public communication as spaces of encounter, for example, public spaces in cities (e.g., Castells, 2008, p. 79), and have been described by Habermas (1962/2013), in his historical analysis, as an important infrastructure for the emergence of the public sphere. One-way communication from a sender to one or more recipients can be thought of spatially as a trajectory. With their logics of differentiation and connection, however, territorial and network spaces are-in our understanding-central to the analysis of public communication. Although places and trajectories also structure public communication, we argue that they form part of network spaces (e.g., places as nodes of a network) and territorial spaces (e.g., trajectories as unidirectional government communication in a city; see also Knoblauch \& Löw, 2020, p. 273).

Having discussed the theoretical implications of understanding public communication as a relational communication space, in the following section we will argue that an empirically grounded perspective on the spatialities of communication profits when the mutual interdependence of socio-material infrastructures and discursive practices is systematically considered. 


\section{Relating Infrastructures and Discursive Practices}

Infrastructures consist of (more or less stable) relations between social goods, which enable, deny, incentivise, or complicate discursive practices (Löw, 2016; Star, 1999). Discursive practices, in turn, are culturally and institutionally embedded, historically routed, and collectively learned practices of meaning-making and knowledge production as well as circulation (Keller, 2005, p. 25). As for their institutional and symbolical stabilisation in time and space, discursive practices establish knowledge orders in highly specialised fields such as in science, issue-centred public communication networks but also with respect to non-discursive practices in everyday social actions, such as making eye contact. These knowledge orders structure social life as they enable actors to communicate about "existing things" suggesting definitions of true, normal, or moral claims by delineating them from their opposites. Knowledge orders can be analysed regarding both their symbolic (interpretative schemes, classifications, phenomenal, and narrative structures) and socio-material dimensions (materiality of infrastructures of knowledge production and circulation). The notion of discursive practices enables us to start from the basic assumption that for any public communication to emerge, practices of meaning-making presuppose socio-material infrastructures of knowledge production and circulation (Keller, 2005, p. 9) as well as collective learning and issue-based experimentation (Sayman, 2020, p. 317). Systemically relating the spatial figures of infrastructures with those of discursive practices points at the structural power relations at play in relational communication spaces (Korn et al., 2019, pp. 31-32; Plantin \& Punathambekar, 2019). This change in perspective is necessary as the history of infrastructures and publics shows that the emergence of a public sphere (Habermas, 1962/2013) historically required congruent scales between publics and infrastructures, especially at local, regional, and national levels (e.g., Schüttpelz, 2017, pp. 27-28). In line with Löw $(2020$, p. 153), we suggest that scales are outcomes of processes of spatial synthesis and thus, are unlike spatial figures, which are spatial arrangements resulting from embodied interaction between subjects and objects. Moving away from focusing solely on scales of communication networks helps to examine the making and complex intermingling of spatial figures by infrastructuring and the emergence of issue-specific discursive practices. These configurations of spatial figures in relational communication spaces exhibit new patterns of social inclusion/exclusion, access, and visibility.

Hence, our perspective emphasises how power relations between "stakeholders and users shape how communication networks are imagined, put in place, and mobilized for different ends" (Plantin \& Punathambekar, 2019 , p. 166). Literature on platforms and datafication has stressed the platformisation of existing infrastructures, which is an effect of the declining modern "infrastructural ideal" of broad service delivered by public monopolists. The digitalisation of public communication by private platform providers generated low cost and dynamic alternatives to legacy media. Based on their ability to create ecosystems around their services, providing interconnectedness and programmability, platform providers have become very powerful actors with infrastructural qualities. Shifting power balances between public and private actors raises the question of which infrastructural ideal could replace the old ideal of a territorially homogenous provision of basic services by public (quasi-)monopolists (Plantin et al., 2018, p. 307). One significant effect of such power asymmetries is that social groups have unequal access to digital infrastructures which has consequences for the discursive practices of the affected communities (Sayman, 2020). We stress that this perspective explicitly includes embodied competencies and social networks as some form of social infrastructure (Pipek \& Wulf, 2009, pp. 456-457).

We link infrastructures and discursive practices systematically in order to enable us to use spatial figures to highlight power relations in processes of public communication. At the same time, it also allows us to shed light on how public communication shapes the spatiality of infrastructures by problematising the consequences of unequal access or representation. In line with Löw's notion of the duality of space, we suggest looking in both directions of the mutual structuration of space and power relations; for example, by looking at conflicts and negotiations concerning spatially extended infrastructures, such as discussion about internet access in rural areas (e.g., Burrell, 2018). It is necessary to specify and differentiate the term 'infrastructures' to show its linkages to discursive practices and to explain why this relation is necessary for the analysis of relational communication spaces.

First, the infrastructures of digital communication networks build on their connections to other major infrastructures, most importantly electricity grids. Interrelations between such major infrastructures are equally important in structuring access and mobility as more narrowly defined relations between discursive practices and infrastructures. However, the sociomateriality of digital communication infrastructures can be separated into four layers: devices and access networks, backbone networks, platforms, and contents (Flensburg \& Lai, 2020). These infrastructural layers arrange socio-material goods in certain configurations, thereby enabling the circulation of data and the occurrence of discursive practices within the infrastructured space. This is because the spatiality of public communication depends on the affordability, accessibility, and reliability of devices for end-users positioned within a multiple infrastructured space. Each level of infrastructure has its own spatial scope and scale, thus incentivising (and inhibiting) certain mediated discursive practices (Plantin \& Punathambekar, 2019). If stabilised across space and time, infrastructures enhance the probability of learning and routinising discursive practices. 
Second, the most striking example for an institutionalised infrastructure is the provision of internet access, which exhibits clear spatial patterns. Empirical analyses with data from Italy and Germany show that there is a positive causal link between the provision of broadband internet on the municipal level and voting for populist parties, suggesting that the provision of infrastructures for digital communication incentivises the occurrence of specific discursive practices, such as the circulation of populists' communication rhetoric and strategies, which also spill over to offline spaces (e.g., Schaub \& Morisi, 2020). Conversely, individuals living in areas without these infrastructures will likely not take part in certain genres of digitalised public communication or may find ways to acquire access to high-speed internet through mobile devices and the internet as opposed to an underground information and telecommunication infrastructure ("mobile-first" strategy; Kersting, 2020, p. 2). This leads to the conclusion that individuals outside infrastructured spaces will probably have fewer opportunities to learn the discursive practices (such as instant messaging, posting, tweeting, blogging, etc.) that enable them to participate in digital networks of public communicationwhich may potentially render them less able to assess information sources.

Third, another important dimension of infrastructures for public communication are educational infrastructures that provide media, information, and digital literacy (Koltay, 2011), or more broadly, any embodied skill helping actors to redesign, use, or configure media infrastructures. Infrastructures for media literacy also exhibit specific spatial patterns. Research in the field of digital inequality in Germany shows that levels of digital literacy and the provision of digital infrastructure correspond with spatial scales (such as rural, suburban, and urban), presenting evidence that rural regions lag behind (Kersting, 2020). Moreover, the spatial dimension of the digital divide overlaps with and reinforces pre-existing patterns of inequality based on age, gender, class, disability, or ethnicity, ultimately leading to an ever faster growing divide of participative inequalities mediated by uneven access to, and different levels of, competency in the use of public communication networks (Kersting, 2020, pp. 5-9). Put simply, places or county types matter in how people can make sense of digital media and infrastructures, which means that the adaptation of a diffusing technology is mediated by individual and structural variables, such as places and spatial scales (Burrell, 2018; Stern et al., 2009). While people in rural areas without a broadband connection in the US have usage patterns for entertainment purposes similar to those who live in urban and suburban contexts, they use the internet less for everyday activities and economic purposes because they lack both digital proficiency and a reliable connection to access high-quality images and content flows (Stern et al., 2009). It becomes evident that these spatially bound conditions of access (Stern et al., 2009, p. 393) are structuring the develop- ment of people's skills in handling the infrastructure and making use of it. Thus, the occurrence of discursive practices requires both access to socio-technical infrastructures and opportunities to learn competencies concerning their usage.

Prior analyses of the relations between infrastructures and discursive practices have highlighted pitfalls of monopolised, missing, or highly manipulative communication infrastructures and the censoring, oppressing, and muting of certain social groups as their digital competencies do not match the affordances of communication infrastructures (or vice versa). One striking example of the relevance for relating discursive practices and infrastructures is the unequal access of different social groups to digital media devices and platforms. This inequality is (among other factors) based on the spatial and physical availability of internet access and the required competencies for making use of it. This leads to a "digital divide" of social groups wherein the relations between infrastructures and discursive practices prestructure how diversely and frequently social groups (not individuals; van Dijk, 2013, p. 109) take part in public communication networks (van Dijk, 2013, p. 114). Consequently, the notion of infrastructures is not limited to technical arrangements of social goods-it also includes digital competencies (see Koltay, 2011, for an overview) of relationally positioned social groups (and their respective categorisations, such as the old/young or urban/rural). Thus, we argue that the intermingling of social and technical infrastructural elements constitutes an infrastructured space inhibiting and/or incentivising the occurrence of specific discursive practices for certain social groups.

The aforementioned arguments exemplify that the making and institutionalisation of spatial figures on different levels of infrastructural layers (socio-technical, media literacy, educational, and economic) should be differentiated from spatial figures as preconditions and effects of discursive practices. This difference serves the need to understand power relations within relational communication spaces playing out on the level of social groups. Differentiating the spatialities of infrastructural layers and discursive practices meets the need to re-relate their figurations in a second step; for example, regarding a certain issue around which public communication emerges, or for exploring why certain communities are hardly (or not at all) present in public communication about controversial matters that affect them.

\section{Operationalising the Relational Communication Space}

Drawing on the sociology of space enables us to undertake differentiated analyses of the spatiality of public communication. Distinguishing the processes of spacing and synthesis helps in understanding two challenges of public communication: the causes of spatial 
heterogeneity within the relational communication space and the different opportunities for participation in public communication. The concept of the relational communication space does not determine a specific spatial configuration, neither theoretically nor normatively. Instead, the spatialisation of public communication is subject to empirical analysis. It can be described and interpreted through the heuristic spatial figures of network and territory (as well as place and trajectory as subordinates). All spatial figures can occur simultaneously and are not mutually exclusive; for example, actors can use different communication infrastructures that enable a more territorially or a more network-like structured communication space. Territorially bound infrastructures can also be integrated into translocal discursive practices. Conversely, potentially globally networked infrastructures can be used for locally bound discourses. Whether the different spatial figures and their logics of connection and differentiation are in conflict or productively complement each other is also a question for empirical analysis.

Additionally, investigating the spatiality of public communication is not an end in itself because we can use the conceptual lens of spatial theory to highlight the effects of structural power relations in and prior to processes of public communication. These can range from social groups being structurally excluded due to a lack of technical infrastructures in a certain area or the overrepresentation of certain voices and communities that are more skilled with the requisite discursive practices (at the cost of others). In addition, it is possible to assess power struggles concerning the spatiality of infrastructures and publics, such as the ongoing discussions about high-speed internet access in rural areas (infrastructures), or conflicts concerning the governance of infrastructures filtering illegal or undesirable media content within certain regulative spaces (mostly territorial), such as the EU (publics). This also allows us to identify development potentials and areas of action: Where do infrastructures fail to do justice to discursive practices? Which infrastructures and resources remain unused? Which skills for participating in public discourse are unequally distributed? Who can participate and who becomes visible in the relational communication space?

How can we translate our theoretical concept of a relational communication space into empirical strategies to answer those questions? The strategies will eventually be determined by the research questions posed, but fundamentally the concept of relational communication space prompts us to work with mixed methods and to incorporate various data sources. This accounts for the infrastructures as well as practices central to the relational communication space. Such approaches can increasingly be found in the social sciences, such as mapping methods (e.g., Karsgaard \& MacDonald, 2020) or netnography (e.g., Kozinets, 2010). Since ours is a relational approach, the collection of network data would be our preferred choice. Combined with content analysis, it is not only the communicative interactions between actors that can be investigated but also their references to places (e.g., Reber, 2020) or actors located in certain places. Moreover, the network represents referenced and addressed goods and human beings. Thus, the network retraces the process of spacing, of putting things and humans into "relational arrangements" (Löw, 2016, p. 131). The network perspective is also well suited to address questions of power structures, visibility, and the ability to connect. For example, network analysis can be used to identify particularly central as well as isolated nodes, the formation of clusters, whose location and topics can be traced, and to analyse the emergence of the different roles that the nodes assume (such as hubs or brokers) which influence the flow of communication (e.g., Himelboim et al., 2017). Methodological strategies that focus on the flows and paths of the object of analysis and map how interconnections are built (grouped under the label of 'following the XY', e.g., an issue or actors), can be applied to explore the full range of infrastructures used to disseminate information or narratives and identify the actors involved (e.g., Ball, 2016; Marres \& Rogers, 2005).

The processes of synthesis, namely the imagination of an audience, the invocation of shared narratives and their perceptions and interpretations (conceptualised here as discursive practices), can be interpreted within the paradigm of (spatial) discourse analysis (e.g., Glasze \& Mattissek, 2009; Witschge, 2008) and understood empirically by well-established methods such as quantitative and qualitative content analysis, as well as interviews (e.g., Burrell, 2018), diary studies (e.g., van Dijk, 2013), multi-sited ethnography (e.g., Marcus, 1995; for a reflection of "ethnographic research in the age of platforms" see Bonini \& Gandini, 2020), and surveys (e.g., Litt \& Hargittai, 2016). Again, these insights will complement the structural network analyses of the goods and humans involved (Jackson \& Foucault Welles, 2016, p. 398). However, using network analysis does not mean that one will only find network spaces of communication. Rather, the relational communication space will present itself as a structure with different spatially structured communicative densifications and infrastructures in which the various spatial figures and their logics overlap and interfere.

\section{Conclusions}

We have set out to develop a concept of the spatiality of public communication because the social and technological developments of the last two decades have shown that the prevailing territorial understanding of space is insufficient to capture the spatiality of public communication. Therefore, we propose the concept of 'relational communication space,' based on Löw's concept of space as a relational arrangement of humans and things (2016, p. 131). Our application of Löw's concept to public communication leads to four conceptual 
innovations regarding theoretical thinking about communication spaces. First, the emergence of public communication spaces can be traced back to two central processes: the use of infrastructures for the purpose of communication, and the synthesis of communicative relations between actors through discursive practices. Second, both infrastructures and discursive practices are spatially bound and thus structure the spatiality of public communication - this is a main contribution of the concept of the relational communication space. Third, the spatial arrangements can be described and interpreted through the simple heuristics of networks and territories. Fourth, the spatiality of infrastructures and discursive practices implies a spatial distribution of (latent) power structures relevant for the investigation of (in)equality in public communication.

What is the added value of this concept for analysing and understanding public communication? While the spatiality of public communication is systematically considered, the spatial configurations are not normatively laden (such as the idea of a unified national public sphere). Instead, our concept is created for the empirical investigation of the spatiality of public communication. The spatial features of infrastructures and discursive practices are indicators of who can participate in public communication and how. By focusing on both dimensions (communication infrastructures and discursive practices), any incongruence or mismatch between the two can be identified, allowing potential interventions to be derived.

We invite future research to apply our concept and to systematically account for the spatiality of public communication. The study of the spatiality of infrastructures, especially their gaps and access restrictions and their role in the emergence of public communication could be particularly interesting for research about media governance. The focus on discursive practices and their implication in synthesising relational communication spaces could be relevant for research investigating agenda building, the diffusion of narratives, frames, etc., and communicative strategies of activists, social movements, or other groups. Fundamentally, the concept of the relational communication space draws our attention toward central questions surrounding the participation, inclusion, and visibility of people and groups from a variety of spatial locations in public communication.

While this article aimed to systematically consider the spatiality of public communication, the integration of another central parameter of human action is still pending. Further developing the concept of relational communication space would require integrating the time dimension. In our argumentation, temporality has been mentioned repeatedly: Infrastructures change through technological developments, which may also affect discursive practices. Discursive practices, in turn, are only formed through repetition. Infrastructures can also shape certain rhythms and affect the speed of communication; for example, digital media enable faster communication than legacy mass media (Kavada \& Poell, 2020 , p. 197). Finally, the discourses that can change infrastructures are also shaped by events that may stretch over years (e.g., the Cambridge Analytica scandal led Facebook to adjust its API while also sparking an ongoing debate about the role of social networking sites in elections and the need for regulation). Considering both the spatiality and temporality will greatly enhance the analysis of the emergence of relational communication spaces.

\section{Acknowledgments}

Funded by the Deutsche Forschungsgemeinschaft (DFG, German Research Foundation)-Projektnummer 290045248-SFB 1265 . The authors would like to thank the reviewers and academic editors for their valuable remarks and constructive feedback on the manuscript.

\section{Conflict of Interests}

The authors declare no conflict of interests.

\section{References}

Abidin, C. (2021). From "networked publics" to "refracted publics": A companion framework for researching "below the radar" studies. Social Media + Society, 7(1), 1-13. https://doi.org/10.1177/2056 305120984458

Adams, P. C., \& Jansson, A. (2012). Communication geography: A bridge between disciplines. Communication Theory, 22(3), 299-318. https://doi.org/ 10.1111/j.1468-2885.2012.01406.x

Ball, S. J. (2016). Following policy: Networks, network ethnography and education policy mobilities. Journal of Education Policy, 31(5), 549-566. https://doi.org/ 10.1080/02680939.2015.1122232

Beck, K. (2003). No sense of place? Das Internet und der Wandel von Kommunikationsräumen [No sense of place? The internet and the transformation of communication spaces]. In C. Funken \& M. Löw (Eds.), Raum-Zeit-Medialität: Interdisziplinäre Studien zu neuen Kommunikationstechnologien [Space-TimeMediality: Interdisciplinary studies on new communication technologies] (pp. 119-137). Springer.

Bonini, T., \& Gandini, A. (2020). The field as a black box: Ethnographic research in the age of platforms. Social Media + Society, 6(4). https://doi.org/ 10.1177/2056305120984477

Burrell, J. (2018). Thinking relationally about digital inequality in rural regions of the U.S. First Monday, 23(6). https://doi.org/10.5210/fm.v23i6.8376

Castells, M. (2008). The new public sphere: Global civil society, communication networks, and global governance. The ANNALS of the American Academy of Political and Social Science, 616(1), 78-93. https:// doi.org/10.1177/0002716207311877 
Chadwick, A. (2011). The political information cycle in a hybrid news system: The British prime minister and the "Bullygate" affair. The International Journal of Press/Politics, 16(1), 3-29. https://doi.org/10.1177/ 1940161210384730

Colleoni, E., Rozza, A., \& Arvidsson, A. (2014). Echo chamber or public sphere? Predicting political orientation and measuring political homophily in Twitter using big data. Journal of Communication, 64(2), 317-332. https://doi.org/10.1111/jcom.12084

Couldry, N. (2014). What and where is the transnationalized public sphere? In K. Nash (Ed.), Transnationalizing the public sphere (pp. 43-59). Polity Press.

Flensburg, S., \& Lai, S. S. (2020). Mapping digital communication systems: Infrastructures, markets, and policies as regulatory forces. Media, Culture \& Society, 42(5), 692-710. https://doi.org/10.1177/ 0163443719876533

Fraser, N. (1990). Rethinking the public sphere: A contribution to the critique of actually existing democracy. Social Text, 25/26, 56-80. https://doi.org/10.2307/ 466240

Fraser, N. (2014). Transnationalizing the public sphere: On the legitimacy and efficacy of public opinion in a post-Westphalian world. In K. Nash (Ed.), Transnationalizing the public sphere (pp. 8-42). Polity Press.

Friedland, L. A., Hove, T., \& Rojas, H. (2006). The networked public sphere. Javnost-The Public, 13(4), 5-26. https://doi.org/10.1080/13183222.2006.110 08922

Glasze, G., \& Mattissek, A. (2009). Diskursforschung in der Humangeographie: Konzeptionelle Grundlagen und empirische Operationalisierungen [Discourse research in human geography: Conceptual foundations and empirical operationalisations]. In G. Glasze \& A. Mattissek (Eds.), Handbuch Diskurs und Raum: Theorien und Methoden für die Humangeographie sowie die sozial- und kulturwissenschaftliche Raumforschung [Handbook discourse and space: Theories and methods for human geography and social and cultural studies of space] (pp. 11-60). transcript.

Habermas, J. (2013). Strukturwandel der Öffentlichkeit: Untersuchungen zu einer Kategorie der bürgerlichen Gesellschaft [Structural transformation of the public sphere: An inquiry into a category of bourgeois society] (13. ed.). Suhrkamp. (Original work published 1962)

Hallin, D. C., \& Mancini, P. (2004). Comparing media systems: Three models of media and politics. Cambridge University Press.

Heft, A., Knüpfer, C., Reinhardt, S., \& Mayerhöffer, E. (2021). Toward a transnational information ecology on the right? Hyperlink networking among rightwing digital news sites in Europe and the United States. The International Journal of Press/Politics, 26(2), 484-504. https://doi.org/10.1177/19401612 20963670

Himelboim, I., Smith, M. A., Rainie, L., Shneider- man, B., \& Espina, C. (2017). Classifying Twitter topic-networks using social network analysis. Social Media + Society, 3(1), 1-13. https://doi.org/10.1177/ 2056305117691545

Jackson, S. J., \& Foucault Welles, B. (2016). \#Ferguson is everywhere: Initiators in emerging counterpublic networks. Information, Communication \& Society, 19(3), 397-418. https://doi.org/10.1080/1369118X. 2015.1106571

Karsgaard, C., \& MacDonald, M. (2020). Picturing the pipeline: Mapping settler colonialism on Instagram. New Media \& Society, 22(7), 1206-1226. https://doi. org/10.1177/1461444820912541

Kavada, A., \& Poell, T. (2020). From counterpublics to contentious publicness: Tracing the temporal, spatial, and material articulations of popular protest through social media. Communication Theory, 31(2), 190-208. https://doi.org/10.1093/ct/qtaa025

Keller, R. (2005). Analysing discourse: An approach from the sociology of knowledge. Forum: Qualitative Social Research, 6(3), Article 32. https://doi.org/ 10.17169/FQS-6.3.19

Kersting, N. (2020). Digitale Ungleichheiten und digitale Spaltung [Digital inequalities and digital divide]. In T. Klenk, F. Nullmeier, \& G. Wewer (Eds.), Handbuch Digitalisierung in Staat und Verwaltung [Handbook digitisation in state and administration] (pp. 1-11). Springer Fachmedien.

Klinger, U. (2018). Aufstieg der Semiöffentlichkeit: Eine relationale Perspektive [The rise of semi-public spheres: A relational perspective]. Publizistik, 63(2), 245-267. https://doi.org/10.1007/s11616-0180421-5

Knoblauch, H., \& Löw, M. (2017). On the spatial refiguration of the social world. Sociologica, 2, 1-27. https://doi.org/10.2383/88197

Knoblauch, H., \& Löw, M. (2020). The re-figuration of spaces and refigured modernity: Concept and diagnosis. Historical Social Research, 45(2), 263-292. https://doi.org/10.12759/HSR.45.2020.2.263-292

Koltay, T. (2011). The media and the literacies: Media literacy, information literacy, digital literacy. Media, Culture \& Society, 33(2), 211-221. https://doi.org/ 10.1177/0163443710393382

Korn, M., Reißmann, W., Röhl, T., \& Sittler, D. (2019). Infrastructuring publics: A research perspective. In M. Korn, W. Reißmann, T. Röhl, \& D. Sittler (Eds.), Infrastructuring publics (pp. 11-47). Springer.

Kozinets, R. V. (2010). Netnography: Doing ethnographic research online. SAGE.

Litt, E., \& Hargittai, E. (2016). The imagined audience on social network sites. Social Media + Society, 2(1), https://doi.org/10.1177/2056305116633482

Löw, M. (2016). The sociology of space: Materiality, social structures and action. Palgrave Macmillan.

Löw, M. (2020). In welchen Räumen leben wir? Eine raumsoziologisch und kommunikativ konstruktivistische Bestimmung der Raumfiguren Territorialraum, 
Bahnenraum, Netzwerkraum und Ort [What spaces do we live in? A spatial sociological and communicative constructivist definition of the spatial figures territorial space, trajectory space, network space and place]. In J. Reichertz (Ed.), Grenzen der Kommunikation: Kommunikation an den Grenzen [Boundaries of communication: Communication at the borders] (pp. 149-164). Velbrück Wissenschaft.

Marcus, G. E. (1995). Ethnography in/of the world system: The emergence of multi-sited ethnography. Annual Review of Anthropology, 24(1), 95-117. https://doi.org/10.1146/annurev.an.24.100195. 000523

Marres, N. (2007). The issues deserve more credit: Pragmatist contributions to the study of public involvement in controversy. Social Studies of Science, 37(5), 759-780. https://doi.org/10.1177/0306 312706077367

Marres, N., \& Lezaun, J. (2011). Materials and devices of the public: An introduction. Economy and Society, 40(4), 489-509. https://doi.org/10.1080/03085147. 2011.602293

Marres, N., \& Rogers, R. (2005). Recipe for tracing the fate of issues and their publics on the web. In B. Latour \& P. Weibel (Eds.), Making things public: Atmospheres of democracy (pp. 922-933). MIT Press.

Meusburger, P. (2001). Geography of knowledge, education, and skills. In N. J. Smelser \& P. B. Baltes (Eds.), International encyclopedia of the social \& behavioral sciences (pp. 8120-8126). Elsevier.

Müller, A.-L., Lossau, J., \& Flitner, M. (2017). Infrastruktur, Stadt und Gesellschaft: Eine Einleitung [Infrastructure, city and society: An introduction]. In M. Flitner, J. Lossau, \& A.-L. Müller (Eds.), Infrastrukturen der Stadt [Infrastructures of the city] (pp. 1-19). Springer.

Neuberger, C. (2017). Die Rückkehr der Masse: Kollektivphänomene im Internet aus Sicht der Massen- und Komplexitätstheorie [The return of the masses: A perspective of mass and complexity theory on collective phenomena on the internet]. Medien \& Kommunikationswissenschaft, 65(3), 550-572. https://doi.org/ 10.5771/1615-634X-2017-3-550

Pfetsch, B. (2018). Dissonant and disconnected public spheres as challenge for political communication research. Javnost-The Public, 25(1/2), 59-65. https://doi.org/10.1080/13183222.2018.1423942

Pfetsch, B., Heft, A., \& Knüpfer, C. (2019). Transnationale Öffentlichkeiten in der Digitalen Gesellschaft: Konzepte und Forschungsperspektiven [Transnational public spheres in the digital society: Concepts and research perspectives]. In J. Hofmann, N. Kersting, C. Ritzi, \& W. J. Schünemann (Eds.), Politik in der digitalen Gesellschaft: Zentrale Problemfelder und Forschungsperspektiven [Politics in the digital society: Central challenges and research perspectives] (pp. 83-101). transcript.

Pipek, V., \& Wulf, V. (2009). Infrastructuring: Toward an integrated perspective on the design and use of information technology. Journal of the Association for Information Systems, 10(5), 447-473. https://doi. org/10.17705/1jais.00195

Plantin, J.-C., Lagoze, C., Edwards, P., \& Sandvig, C. (2018). Infrastructure studies meet platform studies in the age of Google and Facebook. New Media \& Society, 20(1), 293-310. https://doi.org/10.1177/ 1461444816661553

Plantin, J.-C., \& Punathambekar, A. (2019). Digital media infrastructures: Pipes, platforms, and politics. Media, Culture \& Society, 41(2), 163-174. https://doi.org/ $10.1177 / 0163443718818376$

Reber, U. (2020). Global climate change or national climate changes? An analysis of the performance of online issue publics in integrating global issues. Environmental Communication, 15(2), 173-188. https:// doi.org/10.1080/17524032.2020.1812685

Reckwitz, A. (2008). Praktiken und Diskurse [Practices and discourses]. In H. Kalthoff, S. Hirschauer, \& G. Lindemann (Eds.), Theoretische Empirie: Zur Relevanz qualitativer Forschung [Theoretical empiricism: On the relevance of qualitative research] (pp. 188-209). Suhrkamp.

Sayman, V. (2020). Problematische Themen problematischer Öffentlichkeiten: Ulrich Beck und Bruno Latour als Impulsgeber einer Soziologie öffentlicher Praktiken [Problematic issues of problematic publics: Ulrich Beck and Bruno Latour as impulses for a sociology of public practices]. In O. Römer, C. Boehncke, \& M. Holzinger (Eds.), Soziale Welt Sonderband: Soziologische Phantasie und kosmopolitisches Gemeinweisen: Perspektiven einer Weiterführung der Soziologie Ulrich Becks [Soziale Welt special issue: Sociological fantasy and cosmopolitan communities: Perspectives of developing the sociology of Ulrich Beck] (pp. 309-332). Nomos.

Schäfer, M. S., \& Wessler, H. (2020). Öffentliche Kommunikation in Zeiten künstlicher Intelligenz: Warum und wie die Kommunikationswissenschaft Licht in die Black Box soziotechnischer Innovationen bringen sollte [Public communication in times of artificial intelligence: Why and how communication science should crack open the black box of sociotechnical innovations]. Publizistik, 65, 307-331. https:// doi.org/10.1007/s11616-020-00592-6

Schaub, M., \& Morisi, D. (2020). Voter mobilisation in the echo chamber: Broadband internet and the rise of populism in Europe. European Journal of Political Research, 59(4), 752-773. https://doi.org/10.1111/ 1475-6765.12373

Schulz, W. (1990). Die Konstruktion von Realität in den Nachrichtenmedien: Analyse der aktuellen Berichterstattung [The construction of reality in the news media: Analysis of current reporting]. Alber.

Schüttpelz, E. (2017). Infrastructural media and public media. Media in Action, 1, 13-61. http://dx.doi.org/ 10.25819/ubsi/7935 
Star, S. L. (1999). The ethnography of infrastructure. American Behavioral Scientist, 43(3), 377-391. https://doi.org/10.1177/00027649921955326

Stern, M. J., Adams, A. E., \& Elsasser, S. (2009). Digital inequality and place: The effects of technological diffusion on internet proficiency and usage across rural, suburban, and urban counties. Sociological Inquiry, 79(4), 391-417. https://doi.org/10.1111/ j.1475-682X.2009.00302.x

Takhteyev, Y., Gruzd, A., \& Wellman, B. (2012). Geography of Twitter networks. Social Networks, 34(1), 73-81. https://doi.org/10.1016/j.socnet.2011.05. 006

Tarrow, S., \& McAdam, D. (2005). Scale shift in transnational contention. In D. Della Porta \& S. Tarrow (Eds.), Transnational protest and global activism (pp. 121-147). Rowman \& Littlefield.

van Dijk, J. A. G. M. (2013). Digitale Spaltung und digitale Kompetenzen [Digital divide and digital competencies]. In A. Schüller-Zwierlein \& N. Zillien (Eds.), Informationsgerechtigkeit: Theorie und Praxis der gesellschaftlichen Informationsversorgung [Informa- tion justice: Theory and practice of societal information provision] (pp. 108-133). De Gruyter.

Volkmer, I. (2014). The global public sphere: Public communication in the age of reflective interdependence. Polity Press.

Wehden, L.-O., \& Stoltenberg, D. (2019). So far, yet so close: Examining translocal Twitter audiences of regional newspapers in Germany. Journalism Studies, 20(10), 1400-1420. https://doi.org/10.1080/ 1461670X.2018.1520609

Wilke, J., Heimprecht, C., \& Cohen, A. (2012). The geography of foreign news on television: A comparative study of 17 countries. International Communication Gazette, 74(4), 301-322. https://doi.org/ $10.1177 / 1748048512439812$

Wimmer, A., \& Schiller, N. G. (2002). Methodological nationalism and beyond: Nation-state building, migration and the social sciences. Global Networks, 2(4), 301-334.

Witschge, T. (2008). Examining online public discourse in context: A mixed method approach. Javnost-The Public, 15(2), 75-92.

\section{About the Authors}
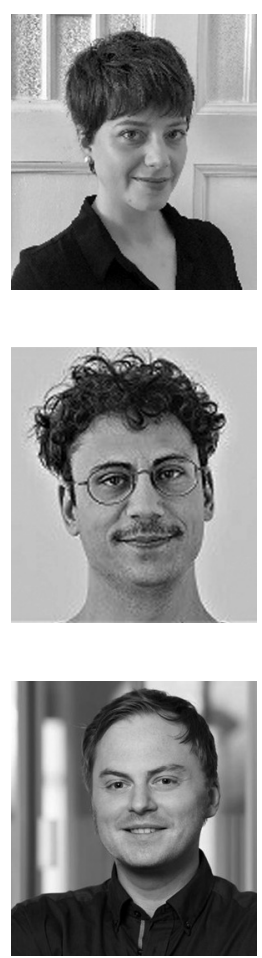

Alexa Keinert (MA) is a Doctoral Candidate at the Institute of Media and Communication Studies at Freie Universität Berlin. As a Research Assistant in the project "Translocal Networks: Public Sphere in the Social Web" at the Collaborative Research Center "Re-Figuration of Spaces" (CRC 1265), she investigates the geographical structure of, and spatial references in, digital public communication. She is interested in the emergence of public communication, communication geography, and mixed methods research.

Volkan Sayman is a Sociologist and Ethnographer. Using insights from Science and Technology Studies, he thinks critically about the shape, usage, and governance of the manifold infrastructures which govern our daily lives. He is trained in a variety of qualitative methods. In the last four years, he has published on power relations playing out in knowledge and digital media infrastructures. Currently, he is investigating the refiguration of public and private spaces as a consequence of increasingly automated mobility systems, such as autonomous cars.

Daniel Maier (Dr. phil.) is a Postdoctoral Researcher and Data Scientist at the German Cancer Consortium. During the time of working on this article, he was a Research Associate at the Institute of Media and Communication Studies at Freie Universität Berlin and the Collaborative Research Center "Re-Figuration of Spaces" (CRC 1265), which is funded by the German Science Foundation (DFG). His research interests include the theory and methods of social networks, computational methods, social media communication, and epidemiology. 